\title{
On Avian Mortality Associated with Human Activities
}

\section{Mortalité aviaire liée aux activités humaines}

\author{
Travis Longcore $^{1,2}$ and Paul A. Smith ${ }^{3}$
}

Key Words: Canada; conservation; editorial; industry; mortality

\section{INRODUCTION}

This special feature of Avian Conservation and Ecology contains a Special Issue of ten articles describing extent and character of avian mortality in Canada associated with human activities. These include estimates of mortality resulting from mowing and other mechanical operations, industrial forestry, domestic cats, collisions with windows, wind turbines, power lines and vehicles, bycatch in commercial fisheries, and both offshore and terrestrial oil and gas exploration and production. These articles contain sector-based assessments of the annual magnitude of the number of eggs or active nests destroyed and number of birds killed as a consequence of a wide range of human activities, excluding habitat development and hunting. This Special Issue represents an unprecedented snapshot of the state of knowledge for such sources of mortality for an entire country at a specific time. Needless to say, numbers of such avian mortalities that can be attributed to humans are large and unevenly distributed among species and different activities.

Researchers and managers often consider human-related mortality of birds to be important only when bird deaths result in a decline of the population of a species (Mayfield 1967), or when a species is killed that is listed as endangered or otherwise protected by law. These standards are, however, inadequate to guide conservation. First, for many species, even large declines are challenging to detect with existing monitoring schemes. Second, the effects of a single stressor are almost impossible to parse unless the focus population is spatially restricted or extraordinarily well monitored. Third, the effects of human-related mortality on other species or on ecosystem processes (Wenny et al. 2011) are not even considered when the standard for action is a documented population decline.

The effects of human-related mortality on bird populations will differ depending on whether mortality is additive to natural mortality or compensatory (Anderson and Burnham
1976, Burnham and Anderson 1984). In the absence of densitydependent processes to stabilize a population, any additional source of mortality would result in decline to extinction. In many instances, however, density-dependent changes in survival, age at maturity, or fecundity compensate for additional mortality. In practice, the response of a population to an additional source of mortality can occur anywhere along a spectrum from an effect greater than additive (depensatory mortality; Liermann and Hilborn 2001) to overcompensation, where survival increases in response to a new cause of mortality, for example because of reduced effects of competition (Boyce et al. 1999, Zipkin et al. 2008).

Discriminating between additive and compensatory mortality is difficult even when monitoring data are extensive and the magnitude of additional mortality is well known (e.g., Schaub and Lebreton 2004, Sandercock et al. 2011). In the papers that follow, authors expended considerable effort to refine estimates of the magnitude of mortality to the extent possible based on the quality of the available data. Yet, in many instances, estimates of human-related mortality are still uncertain and are assessed at the level of taxonomic groups. The actual extent of mortality endured by individual species and, indeed, even the population size of these species, is rarely known with high certainty.

Despite this uncertainty, we can generalize about the likelihood of additional mortality being additive or compensatory. Complete compensation is possible only when additional human-related mortality is lower than natural mortality in its absence (Anderson and Burnham 1976). For example, Ellis et al. 2013 and Calvert et al. 2013 (this Special Feature) report $4 \%$ human-related mortality for the Canadian population of Black-footed Albatross. Current adult survival for this species is $92 \%$, and the natural rate of mortality may be less than 5\% per year (Véran et al. 2007), leaving little room to compensate for human-related mortality of $4 \%$. In contrast, demographic parameters for many bird species suggest ample

\footnotetext{
${ }^{1}$ The Urban Wildlands Group, ${ }^{2}$ University of Southern California Spatial Sciences Institute, ${ }^{3}$ Smith and Associates Ecological Research
}

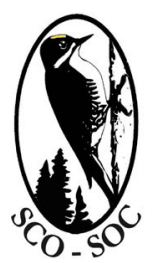

Sponsored by the Society of Canadian Ornithologists and Bird Studies Canada Parrainée par la Société des ornithologistes du Canada et Études d'oiseaux Canada

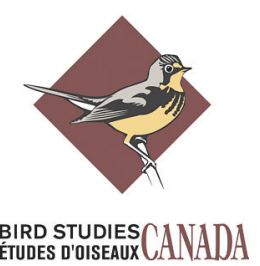


room for compensatory mortality: for example, predators destroy $50 \%$ or more of nests of many open-nesting species (Ricklefs 1969) and small passerines have life histories that accommodate high adult mortality (Wasser and Sherman 2010). The reduced capacity of long-lived, low fecundity species to withstand additional mortality is a pattern documented across a variety of taxa (reviewed in Sandercock et al. 2011), as compared to species with lower survival and higher fecundity.

Population size and status, timing of mortality, and temporal or intersexual variation in mortality can all affect the ability of populations to withstand additional mortality. Densitydependent natural survival is the putative mechanism driving the compensation, so populations at habitat carrying capacity should be more resilient to additional mortality than low density or declining populations (Nichols et al. 1984, Bartmann et al. 1992). Timing of the mortality event also may play a role; mortality is more likely to be additive when it occurs during or after periods of high natural mortality, and more likely to be compensatory when it precedes such periods (Kokko 2001). These generalizations suggest situations where mortality might be more or less likely to have significant effects on population status. Determining the actual demographic effects of such mortality, however, would require spatially explicit study of individual species. For most species, it is not possible to account for heterogeneity in survival between sexes and age classes, for dispersal, and for spatial structure in populations and mortality given the paucity of reliable data.

Dismissing human-related mortality as compensatory, even when populations are well monitored, is a risky bet. Researchers without adequate data can get it wrong. For example, the argument that the high mortality of American Black Duck from hunters was totally compensatory was wrong (Grandy 1983), as documented by Francis et al. (1998) who analyzed 44 years of banding data over three periods of increasingly restrictive harvest regulations and determined that estimated mean survival rates increased from the first to the second period consistent with a model of additivity of hunting mortality. Effects of some sources of mortality may take time to recognize, such as the slow-motion catastrophe for birds caused by second generation anticoagulant rodenticides (Thomas et al. 2011). Many sources of mortality also may work together cumulatively to suppress populations, and at different places across their life cycles (Loss et al. 2012). Assumptions about population-level effects may be misleading if analyzed at the national scale, which may mask effects that are significant at local levels but not evident at coarser spatial scales.

Perhaps more importantly, anthropogenic avian mortality affects more than just the species being killed. When considering effects of human activities on wildlife and ecosystems, the "legacy effects" of habitat loss and degradation are often the focus. Unnatural removal of birds from the environment, however, can still affect ecosystems even if habitat remains intact. If a cat kills a bird, the bird is lost as prey for a raptor (George 1974). If a bird dies from impact against a window and is swept away in the garbage, it cannot be food for its natural decomposers. When a bird is killed as a nestling by a mowing machine, it is not alive to eat insects for several months until it might have otherwise died of natural causes during migration (Whelan et al. 2008). Birds' perception of hazards on the landscape can also have important effects on behavior, with indirect but significant adverse consequences (Bonnington et al. 2013). Disturbance and incidental mortality can alter timing of breeding, habitat use, and foraging behavior-all with the potential to influence ecosystems and ecosystem services. All of these nuances are lost when the focus is only on direct effects on single-species population dynamics.

The value of these ecosystem services is not small and should not be underestimated (Wenny et al. 2011). For example, the natural build-up of fertile soil for agriculture, an ecosystem service dependent on a complex web of organisms, including birds, is estimated to have aggregate value of over $\$ 17$ trillion per year, nearly equivalent to the global Gross National Product (Costanza et al. 1997). Insectivorous birds exert topdown control on populations of invertebrates in many ecosystems, and crop yields are known to be higher in areas where bird populations control populations of herbivorous insects (reviewed in Whelan et al. 2008). In one example, birds raised the income at coffee plantations in Jamaica by \$75-310 per ha per year by controlling populations of crop pests (Kellermann et al. 2008, Johnson et al. 2010). The economic value of birds as dispersers of tree seeds has been estimated at \$2,000-\$9,000 per ha in Sweden (Hougner et al. 2006) and the United States (Tomback, unpublished data, in Wenny et al. 2011). Larger still, given the observed costs to human and livestock health following the collapse of vulture populations in South Asia, the value of vultures' services as scavengers was estimated at \$34 billion for the years 1993-2006 (Markandya et al. 2008). Many of the ecosystem services provided by birds have yet to be translated into economic terms, and scaling up from local examples such as these remains a challenge. The economic contributions made by birds through pest control, pollination, seed dispersal, and scavenging, however, are undoubtedly significant (Whelan et al. 2008, Wenny et al. 2011). Some species of birds also cause economic damage in agriculture and aquaculture, but neither the effects of human-related avian mortality on ecosystem services nor on these disservices is accounted for by singlespecies assessments that focus only on whether populationlevel effects are occurring.

Therefore, in reading and incorporating the contents of the papers that follow, we encourage managers and decision 
makers not to insist on documented species population decline resulting from a single mortality source as the standard of evidence required before action. The world is more complicated than this, and even compensatory mortality has adverse effects on community structure and function. Instead, a precautionary approach is warranted (Cooney 2004), where best management practices to minimize avian mortality are encouraged or required of industries and activities. Improved monitoring and reporting, as advocated in this issue and elsewhere (Loss et al. 2012), and with greater taxonomic specificity (Longcore et al. 2013), is similarly essential. None of these information needs, however, should paralyze decisions to take actions to reduce anthropogenic mortality of birds or to educate the public to advocate for and to implement corrective measures.

\section{LITERATURE CITED}

Anderson, D. R., and K. P. Burnham. 1976. Population ecology of the Mallard: VI. The effect of exploitation on survival. United States Fish and Wildlife Service Resource Publication 128:1-66.

Bartmann, R. M., G. C. White, and L. H. Carpenter. 1992. Compensatory mortality in a Colorado Mule Deer population. Wildlife Monographs 121:3-39.

Bonnington, C., K. J. Gaston, and K. L. Evans. 2013. Fearing the feline: domestic cats reduce avian fecundity through traitmediated indirect effects that increase nest predation by other species. Journal of Applied Ecology 50:15-24. http://dx.doi. org/10.1111/1365-2664.12025

Boyce, M. S., A. R. E. Sinclair, and G. C. White. 1999. Seasonal compensation of predation and harvesting. Oikos 87:419-426. http://dx.doi.org/10.2307/3546808

Burnham, K. P., and D. R. Anderson. 1984. Tests of compensatory vs. additive hypotheses of mortality in Mallards. Ecology 65:105-112. http://dx.doi.org/10.2307/1939463

Calvert, A. M., C. A. Bishop, R. D. Elliot, E. A. Krebs, T. M. Kydd, C. S. Machtans, and G. J. Robertson. 2013. A synthesis of human-related avian mortality in Canada. Avian Conservation and Ecology 8(2): 11. http://dx.doi.org/10.5751/ ACE-00581-080211

Cooney, R. 2004. The precautionary principle in biodiversity conservation and natural resource management: an issues paperforpolicy-makers, researchers and practitioners. World Conservation Union, Gland, Switzerland. [online] URL: http://data.iucn.org/dbtw-wpd/edocs/pgc-002.pdf

Costanza, R., R. D’Arge, R. de Groot, S. Farber, M. Grasson, B. Hannon, K. Limburg, S. Naeem, R. V. O'Neill, and J. Paruelo. 1997. The value of the world's ecosystem services and natural capital. Nature 387:253-260. http://dx.doi. org/10.1038/387253a0
Ellis, J. I., S. I. Wilhelm, A. Hedd, G. S. Fraser, G. J. Robertson, J.-F. Rail, M. Fowler, and K. H. Morgan. 2013. Mortality of migratory birds from marine commercial fisheries and offshore oil and gas production in Canada. Avian Conservation and Ecology 8(2): 4. http://dx.doi.org/10.5751/ACE-00589-080204

Francis, C. M., J. R. Sauer, and J. R. Serie. 1998. Effect of restrictive harvest regulations on survival and recovery rates of American Black Ducks. Journal of Wildlife Management 62:1544-1557. http://dx.doi.org/10.2307/3802021

George, W. G. 1974. Domestic cats as predators and factors in winter shortages of raptor prey. Wilson Bulletin 86:384396.

Grandy, J. W. 1983. The North American Black Duck (Anas rubripes): a case study of 28 years of failure in American wildlife management. International Journal for the Study of Animal Problems 4:1-35.

Hougner, C., J. Colding, and T. Söderqvist. 2006. Economic valuation of a seed dispersal service in the Stockholm National Urban Park, Sweden. Ecological Economics 59:364-374. http://dx.doi.org/10.1016/j.ecolecon.2005.11.007

Johnson, M. D., J. L. Kellermann, and A. M. Stercho. 2010. Pest reduction services by birds in shade and sun coffee in Jamaica. Animal Conservation 13:140-147. http://dx.doi. org/10.1111/j.1469-1795.2009.00310.x

Kellermann, J. L., M. D. Johnson, A. M. Stercho, and S. C. Hackett. 2008. Ecological and economic services provided by birds on Jamacan Blue Mountain coffee farms. Conservation Biology 22:1177-1185. http://dx.doi.org/10.1111/ j.1523-1739.2008.00968.x

Kokko, H. 2001. Optimal and suboptimal use of compensatory responses to harvesting: timing of hunting as an example. Wildlife Biology 7:141-150.

Liermann, M., and R. Hilborn. 2001. Depensation: evidence, models and implications. Fish and Fisheries 2:33-58. http:// dx.doi.org/10.1046/j.1467-2979.2001.00029.x

Longcore, T., C. Rich, P. Mineau, B. MacDonald, D. G. Bert, L. M. Sullivan, E. Mutrie, S. A. Gauthreaux, Jr., M. L. Avery, R. L. Crawford, A. M. Manville, II, E. R. Travis, and D. Drake. 2013. Avian mortality at communication towers in the United States and Canada: which species, how many, and where? Biological Conservation 158:410-419. http://dx.doi.org/10.1016/ j.biocon.2012.09.019

Loss, S. R., T. Will, and P. P. Marra. 2012. Direct humancaused mortality of birds: improving quantification of magnitude and assessment of population impact. Frontiers in Ecology and the Environment 10:357-364. http://dx.doi. org/10.1890/110251 
Markandya, A., T. Taylor, A. Longo, M. N. Murty, S. Murty, and K. Dhavala. 2008. Counting the cost of vulture declinean appraisal of the human health and other benefits of vultures in India. Ecological Economics 67:194-204. http://dx.doi. org/10.1016/j.ecolecon.2008.04.020

Mayfield, H. 1967. Shed few tears. Audubon Magazine 69:6165.

Nichols, J. D., M. J. Conroy, D. R. Anderson, and K. P. Burnham. 1984. Compensatory mortality in waterfowl populations: a review of the evidence and implications for research and management. Transactions of the North American Wildlife and Natural Resources Conference 49:535554.

Ricklefs, R. E. 1969. An analysis of nesting mortality in birds. Smithsonian Contributions to Zoology 9:1-48. http://dx.doi. org/10.5479/si.00810282.9

Sandercock, B. K., E. B. Nilsen, H. Brseth, and H. C. Pedersen. 2011. Is hunting mortality additive or compensatory to natural mortality? Effects of experimental harvest on the survival and cause-specific mortality of willow ptarmigan. Journal of Animal Ecology 80:244-258. http://dx.doi.org/10.1111/ j.1365-2656.2010.01769.x

Schaub, M., and J.-D. Lebreton. 2004. Testing the additive versus the compensatory hypothesis of mortality from ring recovery data using a random effects model. Animal Biodiversity and Conservation 27:73-85.

Thomas, P. J., P. Mineau, R. F. Shore, L. Champoux, P. A. Martin, L. K. Wilson, G. Fitzgerald, and J. E. Elliott. 2011. Second generation anticoagulant rodenticides in predatory birds: probabilistic characterisation of toxic liver concentrations and implications for predatory bird populations in Canada. Environment International 37:914-920. http://dx. doi.org/10.1016/j.envint.2011.03.010

Véran, S., O. Gimenez, E. Flint, W. L. Kendall, P. F. Doherty, Jr., and J.-D. Lebreton. 2007. Quantifying the impact of longline fisheries on adult survival in the black-footed albatross. Journal of Applied Ecology 44:942-952. http://dx. doi.org/10.1111/j.1365-2664.2007.01346.x

Wasser, D. E., and P. W. Sherman. 2010. Avian longevities and their interpretation under evolutionary theories of senescence. Journal of Zoology 280:103-155. http://dx.doi. org/10.1111/j.1469-7998.2009.00671.x

Wenny, D. G., T. L. DeVault, M. D. Johnson, D. Kelly, C. H. Sekercioglu, D. F. Tomback, and C. J. Whelan. 2011. The need to quantify ecosystem services provided by birds. Auk 128:1-14. http://dx.doi.org/10.1525/auk.2011.10248
Whelan, C. J., D. G. Wenny, and R. J. Marquis. 2008. Ecosystem services provided by birds. Annals of the New York Academy of Sciences 1134:25-60. http://dx.doi.org/10.1196/ annals. 1439.003

Zipkin, E. F., P. J. Sullivan, E. G. Cooch, C. E. Kraft, B. J. Shuter, and B. C. Weidel. 2008. Overcompensatory response of a smallmouth bass (Micropterus dolomieu) population to harvest: release from competition? Canadian Journal of Fisheries and Aquatic Sciences 65:2279-2292. http://dx.doi. org/10.1139/F08-133 